\title{
Pengaruh Media Dan Periode Simpan Terhadap Viabilitas Benih Cengkeh Tuni (Syzygium aromaticum L.)
}

\author{
The Influence of The Media and Storage Period on The Viability of The Clove Seeds (Syzygium \\ aromaticum L.)
}

\section{Marselina Noya, Johan Riry*, dan Marthini Lesilolo}

\author{
Jurusan Budidaya Pertanian Fakultas Pertanian Universitas Pattimura, Jl. Ir. M. Putuhena Kampus Poka Ambon \\ 97233, Indonesia \\ *Penulis Korespondensi: e-mail: riryjohan@yahoo.com
}

\begin{abstract}
This study aims to examine the influence of the media and the storage period on the viability of clove seeds. The study was conducted at the Ambon Plant Crops Protection and Protection Center laboratory. The study used a factorial completely randomized design with two types of factors and three replications. The storage media consists of 3 levels, namely: Without the storage media, the media for storing rice husk and the media for storing sawdust. The second factor is the storage period consists of 4 levels, namely: 10 days storage, 20 days storage, 30 days storage and 40 days storage. The parameters measured were germination power, germination rate, and vigor index. Storage media and storage period significantly affected germination and vigor indexes but did not significantly affect germination rates. The results showed that the sawdust storage media was a good medium for storing clove seeds (Syzygium aromaticum L.). This can be seen in the results of the average germination of clove seeds stored in powder storage media with a storage time of 10 days giving better results of $85 \%$ compared to rice husks at a storage time of 10 days with a germination percentage of $65 \%$.
\end{abstract}

Keywords: clove seeds, save media, save period

\section{ABSTRAK}

Penelitian ini bertujuan untuk menguji pengaruh media dan periode simpan terhadap viabilitas benih cengkeh. Penelitian dilaksanakan di laboratorium Balai Besar Perbenihan dan Proteksi Tanaman Perkebunan Ambon. Penelitian menggunakan rancangan acak lengkap pola faktorial dengan dua macam faktor dan tiga kali ulangan. Media simpan terdiri dari 3 taraf yaitu: Tanpa media simpan, media simpan sekam padi dan media simpan serbuk gergaji. Faktor kedua adalah periode simpan terdiri dari 4 taraf yaitu: penyimpanan 10 hari, penyimpanan 20 hari, penyimpanan 30 hari dan penyimpanan 40 hari. Parameter yang diukur adalah daya berkecambah, laju perkecambahan dan indeks vigor. Media simpan dan periode penyimpanan berpengaruh nyata pada persentase perkecambahan dan indeks vigor tetapi tidak berpengaruh nyata pada laju perkecambahan. Hasil penelitian menunjukan bahwa media simpan serbuk gergaji merupakan media yang baik bagi penyimpanan benih cengkeh (Syzygium aromaticum L.). Hal ini terlihat pada hasil rata-rata daya berkecambah benih cengkeh yang disimpan pada media simpan serbuk dengan lama penyimpanan selama 10 hari memberikan hasil yang lebih baik yakni $85 \%$ jika dibandingkan dengan sekam padi pada lama penyimpanan 10 hari dengan persentase perkecambahan $65 \%$.

Kata Kunci: benih cengkeh, media simpan, periode simpan

\section{PENDAHULUAN}

Tanaman cengkeh (Syzygium aromaticum L) termasuk dalam suku Myrtaceae, merupakan salah satu tanaman asli Indonesia yang berasal dari kepulauan Maluku. Tanaman ini merupakan tanaman yang termasuk dalam kategori rempah-rempah dan pemanfaatannyajuga dapat digunakan sebagai bahan obat. Hasil utama tanaman cengkeh adalah bunga cengkeh yang dipanen pada saat kelopak bunga belum mekar. Bunga cengkeh kering merupakan salah satu bahan baku utama untuk rokok kretek yang merupakan rokok khas Indonesia (Anonim, 2009).

Usahatani pembenihan cengkeh untuk saat ini dan ditahun-tahun mendatang sangatlahpenting untuk diusahakan. Hal tersebut disebabkan sebagian besar kondisi tanaman cengkeh di Indonesia termasuk di kepulauan Maluku sudah termasuk tanaman tua, dimana produksinya rendah dan sudah tidak produktif lagi, dengan demikian potensi kebutuhan bibit cengkeh untuk 
rehabilitasi tanaman tua dan pengembangan baru sangat besar. Pada tahun 1995 produksi cengkeh nasional mencapai 90.007 ton, kemudian turun menjadi 52.903 ton pada saat penen kecil tahun 1999. Pada tahun 2002 mencapai 79.00 ribu ton pada saat panen besar dan pada tahun 2012 produksi cengkeh mencapai 79,25 ribu ton. Di tahun 2015 produksi cengkeh mencapai 137.721 ribu ton. Di lain pihak kebutuhan cengkeh untuk rokok kretek dan ekspor rata-rata 215.645 ribu ton/tahun. Terjadinya kekurangan pasokan tersebut merupakan tantangan bagi petani dan pengusaha untuk dapat memenuhinya dengan menyeimbangkan antara pasokan dan permintaan cengkeh. Hal ini dapat dilakukan melalui peremajaan tanaman yang didukung dengan harga beli yang layak (Ditjenbun, 2016).

Tanaman cengkeh dapat diperbanyak secara generatif dan vegetatif. Perbanyakan cengkeh lebih banyak dilakukan secara generatif. Permasalahan yang dihadapi dalam pengadaan benih cengkeh secara generatif antara lain karakteristik benih cengkeh yang tidak dapat disimpan lama karena bersifat rekalsitran. Karena sifat itulah yang menyebabkan menurunnya viabilitas yang cepat dari benih cengkeh. Hal ini menimbulkan kesulitan jika benih harus di kirim dari suatu tempat produksi benih ke tempat konsumen benih sehingga kondisi tersebut memerlukan adanya penanganan benih atau teknik penyimpanan yang tepat agar viabilitas benih masih dapat dipertahankan (Ditjenbun, 1985).

Sehubungan dengan proses penyimpanan maka tempat atau media penyimpanan juga merupakan faktor yang penting untuk diperhatikan. Media simpan benih yang baik adalah media yang dapat menyerap gas dan kelembaban, menahan pertukaran air dan udara luar juga memelihara hidupnya embrio. Disamping itu penyimpanan sangat memerlukan kondisi yang tidak memungkinkan untuk serangga dan cendawan berkembang biak (Sadjad, 1980). Salah satu usaha mempertahankan kadar air benih adalah dengan menyimpan benih pada media simpan yang padat lembab seperti serbuk gergaji, karna serbuk gergaji mempunyai sifat lambat lapuk dan media ini sangat baik menyimpan air sehingga dapat mempertahankan kelembaban disekitar benih (Sumampow, 2010). Selain media simpan serbuk gergaji juga terdapat sekam padi yang sering digunakan sebagai media simpan benih.

Berdasarkan uraian diatas maka dilakukan penelitian untuk mengetahui dan menentukan pengaruh media dan periode simpan terhadap viabilitas benih cengkeh (S. aromaticum L).

Penelitian ini bertujuan untuk menghasilkan pengaruh media simpan dan periode simpan terhadap viabilitas benih cengkehtuni (S. aromaticum $\mathrm{L})$.

\section{METODE PENELITIAN}

\section{Lokasi dan Waktu Penelitian}

Penelitian dilakukan di Laboratorium Balai Besar Perbenihan dan Proteksi Tanaman Perkebunan
Ambon. Penelitian dilasanakan pada bulan Juni sampai bulan Agustus 2017.

\section{Alat dan Bahan}

Oven, thermohigrometer, timbangan analitik, kertas label, pisau, benih cengkeh tuni, pasir steril, serbuk gergaji, sekam padi, air, plastik bening (zipper bag) ukuran $20 \times 30 \mathrm{~cm}$.

\section{Rancangan Percobaan}

Dalam penelitian ini digunakan Rancangan Acak Lengkap pola faktorial (Yitnosumarto, 1993) dengan dua macam faktor dan tiga kali ulangan. Faktorpertama adalah media simpan (A), terdiri dari 3 taraf yaitu: tanpa media simpan (A0), sekam padi (A1) dan serbuk gergaji (A2). Faktor kedua adalah periode simpan (B), terdiri dari lima taraf yaitu: tanpa penyimpanan (B0), penyimpanan 10 hari (B1), penyimpanan 20 hari (B2), penyimpanan 30 hari (B3), penyimpanan 40 hari (B4). Dengan demikian diperoleh 15 satuan percobaan. Setiap perlakuan diulang tiga kali sehingga jumlah satuan percobaan sebanyak 45 satuan percobaan.Benih yang digunakan dalam penelitian ini berjumlah 2.250 dengan jumlah setiap satuan percobaan 150 benih. Pengujian kadar air digunakan benih sebanyak 300 benih. Hasil penelitian dianalisis dengan menggunakan sofware Minitab 17.

\section{Prosedur Penelitian}

\section{Persiapan Benih}

Benih cengkeh yang digunakan dalam penelitian adalah jenis cengkeh tuni dari Desa Oma Kecamatan Haruku. Sumber benih diperoleh dari pohon cengkeh milik Bapak Nus Uniputty. Benih cengkeh diambil dari buah yang telah masak fisiologis (berwarna ungu kehitaman, bebas hama penyakit, tidak cacat, tidak ada bekas luka atau bercak hitam yang menandakan benih terserang jamur, berat minimal $1 \mathrm{~g}$, panjang $2,5 \mathrm{~cm}$, diameter $1-2 \mathrm{~cm}$.

\section{Penyiapan Media Simpan}

Media simpan yang digunakan dalam penelitian ini adalah sekam padi dan serbuk gergaji. Media tersebut disterilkan dengan cara di jemur dibawah sinar matahari selama 2 hari.

Pengukuran kadar air awal benih dilakukan sebelum penyimpanan dan diakhir penyimpanan sesuai periode simpan yang ditentukan. Pengujian kadar air dalam penelitian digunakan benih sebanyak 300, yaitu dengan melakukan penimbangan dan pengeringan oven suhu $103^{\circ} \mathrm{C}$ selama $17 \mathrm{jam}$. Kemudian kandungan kadar air benih dihitung dengan mengggunakan rumus:

$$
\mathrm{KA}=\frac{\mathrm{M} 2-\mathrm{M} 3}{\mathrm{M} 2-\mathrm{M} 1} \times 100 \%
$$

Keterangan: $\mathrm{M} 1$ = Berat cawan porselin $(\mathrm{g}) ; \mathrm{M} 2=$ Berat cawan + benih sebelum pengeringan; dan $\mathrm{M} 3=$ Berat cawan + benih setelah pengeringan 


\section{Penempatan Benih dalam Media Simpan}

Benih yang digunakan dalam penelitian ini berjumlah 2.250 dengan jumlah setiap satuan percobaan 150 benih. Wadah yang digunakan untuk menyimpan benih cengkeh adalah kantong plastik bening. Dalam setiap kantong plastik diisi dengan media simpan serbuk gergaji dan sekam padi, masing-masing sebanyak $350 \mathrm{~g}$.

\section{Penyimpanan}

Benih cengkeh dimasukan dalam kantongberisi media simpan kemudian di beri label. Selanjutnya disimpan dalam ruangan laboratorium di ruang penyimpanan benih sesuai dengan jangka waktu penyimpanan benih yang telah ditentukan.

\section{Penanaman}

Media perkecambahan yang digunakan adalah pasir steril. Strilisasi pasir dilakukan dengan cara dicuci kemudian disangrai di atas api selama 3 jam. Pasir steril dimasukan dalam bak kecambah yang telah disiapkan. Sesuai periode simpan yang telah ditentukan, benih kemudian dikeluarkan dari media simpan dan dilakukan pengupasan kulit buah dengan hati-hati agar benih tidak terluka. Benih cengkeh dikecambahkan pada bak kecambah dengan jarak tanam $2 \times 2 \mathrm{~cm}$ (Balittro, 2014).

\section{Variabel Pengamatan}

\section{Daya Kecambah}

Daya kecambah, dengan menghitung jumlah kecambah normal selama jangka waktu 30 hari (Permentan No. 50, 2015) dengan menggunakan rumus ISTA dalam Kuswanto (1997).

$\mathrm{DK}=\frac{\text { Jumlah kecambah normal yang dihasilkan }}{\text { Jumlah contoh benih yang diuji }} \times 100 \%$

\section{Laju Perkecambahan}

Laju perkecambahan, diukur dengan menghitung jumlah hari yang diperlukan untuk munculnya radikal selama jangka waktu tertentu (30 hari pengamatan). Menurut Sadjad dkk. (1974/1975) dalam Sutopo (2002).

$$
\mathrm{LP}=\frac{\mathrm{N}_{1} \mathrm{~T}_{1}+\mathrm{N}_{2} \mathrm{~T}_{2}+\ldots \ldots+\mathrm{N}_{\mathrm{n}} \mathrm{T}_{\mathrm{n}}}{\text { Jumlah Total Benih yang Berkecambah }}
$$

Keterangan: LP = Laju perkecambahan; $\mathrm{N}=$ Jumlah benih yang berkecambah pada satuan waktu tertentu; $\mathrm{T}$ = Jumlah waktu antara awal pengujian sampai akhir dariinterval tertentu suatu pengamatan

\section{Indeks Vigor}

Untuk vigor benih parameter yang diukur adalah kecepatan berkecambah yang dihitung menggunakan rumus yang dikemukakan oleh Kotowski (1972) dan Copeland (1979) dalam Kartasapoetra (2003) sebagai berikut:

$$
\mathrm{IV}=\frac{\mathrm{G} 1}{\mathrm{D} 1}+\frac{\mathrm{G} 1}{\mathrm{D} 2}+\frac{\mathrm{G} 3}{\mathrm{D} 3}+\frac{\mathrm{Gn}}{\mathrm{Dn}}
$$

Keterangan: IV = Indeks Vigor; $G=$ Jumlah benih yang berkecambah pada hari tertentu; $\mathrm{D}=$ Waktu yang bersesuaian dengan jumlah tertentu; $\mathrm{N}=$ Jumlah hari pada perhitungan terakhir.

\section{HASIL}

Hasil analisis statistik untuk melihat pengaruh media dan periode simpan terhadap viabilitas benih cengkeh $(S$. aromaticum $\mathrm{L})$ secara umum dapat dilihat pada Tabel 1 .

\section{Hasil Uji Beda Rataan Untuk Perlakuan Media Simpan}

Hasil analisis keragaman perlakuan media simpan memberi pengaruh terhadap daya kecambah dan indeks vigor benih. Hasil uji beda rataan untuk perlakuan media simpan dapat dilihat pada Tabel 2.

Dari Tabel 2 dapat diketahui bahwa pada peubah daya kecambah menunjukan bahwa perlakuan media simpan serbuk gergaji memberikan nilai tertinggi yakni $59,20 \%$ berbeda nyata dengan perlakuan media simpan sekam padi $46,40 \%$ dan perlakuan tanpa media simpan $38,26 \%$. Pada peubah indeks vigor menunjukan nilai tertinggi pada perlakuan media simpan serbuk gergaji sebesar $14,35 \%$ dan tidak berbeda nyata dengan perlakuan media simpan sekam padi yakni 10,07\% tetapi berbeda nyata denganperlakuan tanpa media simpan yakni $8,56 \%$.

\section{Hasil Uji Beda Rataan Untuk Perlakuan Periode Simpan}

Hasil analisis keragaman perlakuan periode simpan memberi pengaruh terhadap daya kecambah, laju perkecambahan dan indeks vigor benih. Hasil uji beda rataan untuk perlakuanperiode simpan dapat dilihat pada Tabel 3 .

Tabel 1. Rekapitulasi hasil analisis keragaman untuk semua peubah pada berbagai perlakuan media dan periode simpan terhadap viabilitas benih cengkeh (Syzygium aromaticum $\mathrm{L}$ )

\begin{tabular}{lccc}
\hline \multirow{2}{*}{ Perlakuan } & \multicolumn{3}{c}{ Variabel Pengamatan } \\
\cline { 2 - 4 } & Daya Kecambah (DK) & Laju Perkecambahan (LP) & Indeks Vigor (IV) \\
\hline Media Simpan (A) & $*$ & tn & $*$ \\
Periode Simpan (B) & $*$ & $*$ & $*$ \\
Interaksi (AxB) & $*$ & tn & $*$ \\
\hline
\end{tabular}

Keterangan: $*$ nyata, $\mathrm{tn}=$ tidaknyata 
Tabel 2. Hasil uji beda rataan daya kecambahdan indeks vigor benihpada berbagai perlakuan media simpan

\begin{tabular}{|c|c|c|}
\hline \multirow{2}{*}{ Perlakuan Media Simpan } & \multicolumn{2}{|c|}{ Rataan } \\
\hline & DayaKecambah (\%) & IndeksVigor (\%) \\
\hline Serbuk gergaji (A2) & $59,20 \quad \mathrm{a}$ & $14,35 \quad \mathrm{a}$ \\
\hline Sekam padi (A1) & 46,40 & 10,07 \\
\hline Tanpa media simpan (A0) & 38,26 & 8,56 \\
\hline BNT 0.05 & 3,36 & 0,82 \\
\hline
\end{tabular}

Keterangan: Angka-angka yang diikuti dengan huruf yang sama tidak berbeda menurut Uji BNT 0,05

Tabel 3. Hasil uji beda rataan daya berkecambah, laju perkecambahan dan indeks vigor benih cengkeh (Syzygium aromaticum L.) pada berbagai perlakuan periode simpan

\begin{tabular}{|c|c|c|c|c|}
\hline \multirow{2}{*}{ Perlakuan Periode Simpan } & \multicolumn{4}{|c|}{ Rataan } \\
\hline & DK & & LP & IV \\
\hline Tanpa penyimpanan (B0) & 97,77 & $\mathrm{a}$ & $13,98 \mathrm{a}$ & $19,39 \mathrm{a}$ \\
\hline Penyimpanan 10 hari (B1) & 70,88 & $\mathrm{~b}$ & $9,08 \mathrm{a}$ & $15,61 \mathrm{a}$ \\
\hline Penyimpanan 20 hari (B2) & 32,00 & $\mathrm{c}$ & $3,91 \mathrm{~b}$ & $10,02 b$ \\
\hline Penyimpanan 30 hari (B3) & 24,00 & $\mathrm{~d}$ & $3,08 \mathrm{~b}$ & $4,94 \mathrm{c}$ \\
\hline Penyimpanan 40 hari (B4) & 15,11 & $\mathrm{e}$ & $2,18 \mathrm{~b}$ & $3,36 \mathrm{c}$ \\
\hline BNT 0.05 & 4,34 & & 1,50 & 1,05 \\
\hline
\end{tabular}

Keterangan: Angka-angka yang diikuti dengan huruf yang sama tidak berbeda menurut Uji BNT 0,05

Hasil uji beda rataan pada Tabel 3 menunjukan bahwa pada peubah daya kecambah masing-masing perlakuan memberi pengaruh yang berbeda. Perlakuan tanpa penyimpanan memiliki nilai tertinggi yakni $97,77 \%$ dan diikuti oleh perlakuan penyimpanan 10 hari (70,88\%), perlakuan penyimpanan 20 hari $(32,00 \%)$, perlakuan penyimpanan 30 hari $(24,00 \%)$ dan nilai terendah pada perlakuan penyimpanan 40 hari yakni $15,11 \%$. Pada peubah laju perkecambahan perlakuan tanpa penyimpanan memiliki nilai tertinggi sebesar 13,98 dan berbeda nyata dengan perlakuan penyimpanan 20 hari $(3,91)$, perlakuan penyimpanan 30 hari $(3,08)$ dan perlakuanpenyimpanan 40 hari $(2,18)$ tetapi tidak berbeda nyata dengan perlakuan penyimpanan 10 hari $(9,08)$. Pada peubah indeks vigor perlakuan tanpa penyimpanan memiliki nilai tertinggi yakni 13,98 dan berbeda nyata dengan perlakuan penyimpanan 20 hari $(10,02)$, perlakuan penyimpanan 30 hari $(4,94)$ dan perlakuan penyimpanan 40 hari $(3,36)$ tetapi tidak berbeda nyata dengan perlakuan penyimpanan 10 hari $(15,61)$.

\section{Hasil Uji Beda Rataan Untuk Interaksi Antara Media Simpan dan Periode Simpan}

Hasil analisis keragaman terhadap semuapeubah didapati bahwa interaksi antara media simpan dan periode simpan memberi pengaruh pada daya kecambah dan indeks vigor benih cengkeh. Hasil uji beda rataan dapat dilihat pada Tabel 4.

Dari Tabel 4, hasil uji beda rataan daya kecambah dan indeks vigor benih cengkehpada interaksi berbagai perlakuan media dan periode simpan dapat diketahui bahwa pada peubah daya kecambah perlakuan A2B0 $(99,33)$ berbeda nyata dengan perlakuan A2B1 $(85,33)$, A1B1 $(65,33)$, A0B1 $(57,33)$, A2B2 $(48,66)$,
A2B3 (35,33), A1B2 (29,33), A2B4 (27,33), A1B3 $(24,66)$, A0B2 $(18,00)$, A1B4 $(15,33)$, A0B3 $(12,00)$, A0B4 $(7,33)$ tetapi tidak berbeda nyata dengan perlakuan A1B0 $(97,33)$ dan A0B0 $(96,66)$. Pada peubah indeks vigor perlakuan A2B0 $(20,00)$ berbeda nyata dengan perlakuan A1B1 $(15,48)$, A0B1 $(12,81)$, A2B2 (14,51), A2B3 (7,82), A1B2 $(8,34)$, A2B $4(5,90)$, A1B3 $(4,45)$, A0B2 $(7,18)$, A1B4 $(2,75)$, A0B3 $(2,56)$, A0B4 tetapi tidak berbeda nyata dengan perlakuan A1B0 $(19,36)$, A0B0 $(18,81)$ dan A2B1 $(18,54)$.

\section{PEMBAHASAN}

\section{Pengaruh Media Simpan Terhadap Viabilitas Benih Cengkeh}

Upaya perbanyakan tanaman merupakan langkah awal dalam proses budidaya suatu tanaman untuk menentukan keberhasilan budidaya selanjutnya. Dalam hubungan dengan penyediaan benih bermutu, penggunaan benih asalan akan menyebabkan produktivitas tanaman rendah. Syarat benih cengkeh bermutu selain berasal dari varietas unggul yang telah terjamin mutu genetisnya, benih yang dihasilkan harus memiliki mutu fisiologis dan genetis yang baik. Mutu fisiologis benih mencerminkan kemampuan benih untuk bisa hidup normal dalam kisaran keadaan alam yang cukup luas, mampu tumbuh cepat dan merata, serta dapat disimpan. Mutu genetis benih menunjukkan tingkat kemurnian varietas yang dihasilkan dari kinerja pemuliaan tanaman atau tingkat keterwakilan keragaman genetik suatu sumber benih (Sadjad,1980).

Tujuan utama penyimpanan benih adalah untuk mempertahankan viabilitas yang maksimum selama mungkin sehingga dalam hal penyimpanan diperlukan suatu teknik penyimpanan dengan mengkombinasikan 
berbagai faktor perlakuan selama proses tersebut berlangsung (Sutopo, 1993).

Viabilitas adalah kemampuan benih atau daya hidup benih untuk tumbuh secara normal pada kondisi optimum. Berdasarkan pada kondisi lingkungan pengujian viabilitas benihdikelompokkan ke dalam viabilitas benih dalam kondisi lingkungan sesuai (favourable) dan viabilitas benih dalam kondisi lingkungan tidak sesuai (unfavourable). Pengujian viabilitas benih dalam kondisi lingkungan tidak sesuai termasuk dalam pengujian vigor benih. Perlakuan dengan kondisi lingkungan sesuai sebelum benih dikecambahkan tergolong untuk menduga parameter vigor daya simpan benih, sedangkan jika kondisi lingkungan tidak sesuai diberikan selama pengecambahan benih makatergolong dalam pengujian untuk menduga parameter viabilitas tumbuh benih (Sudjadi, 2006).

Kegiatan pengiriman dan penyimpanan benih dapat menyebabkan terjadinya penurunan viabilitas benih. Apabila kemasan, media dan kondisi penyimpanan tidak sesuai maka kadar benih akan menurun secara berlebihan. Hal ini dapat menyebabkan terjadinya penurunan viabilitas benih secara drastis sehingga mencapai daya tumbuh dibawah $50 \%$. Untuk itu, penelitian yang dilakukan saat ini diharapkan dapat memberikan informasi tentang penggunaan media simpan dan lama penyimpanan yang tepat sehingga tingkat penurunan viabilitas dapat ditekan selama masa penyimpanan khususnya untuk benih-benih yang bersifat rekalsitran seperti cengkeh (S. aromaticum L.).

Berdasarkan hasil pengamatan daya kecambah benih cengkeh menunjukan bahwa daya kecambah benih cengkeh bervariasi menurut lama penyimpanan dan media simpan yang digunakan. Pada lama penyimpanan 10 hari, 20 hari, 30 hari dan 40 hari pada media simpan sekam padi dan media simpan serbuk gergaji memberikan hasil perkecambahan yang berbeda.

Berdasarkan hasil penelitian, diketahui bahwa benih yang disimpan didalam media simpan serbuk gergaji (A2) memberikan hasil yang lebih baik jika dibandingkan dengan benih yang disimpan pada media simpan sekam padi (A1) dan diikuti oleh persentase perkecambahan terendah pada perlakuan penyimpanan tanpa media simpan (A0). Hal senada juga disampaikan oleh Sumampow (2010), bahwa serbuk gergaji lebih baik untuk penyimpanan benih dari pada media simpan sabut kelapa. Persentase kelangsungan hidup bibit, jumlah daun dan tinggi bibit setelah disimpan selama 35 hari dalam media simpan serbuk gergaji lembab lebih tinggi daripada persentase kelangsungan hidup bibit yang disimpan dalam media simpan sabut kelapa lembab.

Benih yang memiliki daya berkecambah yang baik adalah benih yang memiliki nilai persentase perkecambahan yang tinggi. Hasil penelitian menunjukan bahwa nilai persentase perkecambahan yang tertinggi adalah pada benih cengkeh yang disimpan pada media simpan serbuk gergaji dengan nilai rata-rata perkecambahan $59.20 \%$ bila dibandingkan dengan benih cengkeh yang disimpan pada media simpan sekam padi dengan nilai rata-rata perkecambahan $46.40 \%$.

Daya kecambah dan indeks vigor benih pada media simpan serbuk gergaji menunjukan hasil yang lebih baik dari media simpan sekam padi dan penyimpanan tanpa media simpan.

Tabel 4. Uji beda rataan daya kecambah dan indeks vigor benih cengkeh pada berbagai perlakuan media simpan dan periode simpan

\begin{tabular}{crrrr}
\hline \multirow{2}{*}{$\begin{array}{c}\text { Interaksi Media Simpan dan } \\
\text { Periode simpan }\end{array}$} & \multicolumn{3}{c}{ Rataan } \\
\cline { 2 - 5 } & \multicolumn{2}{c}{ DK } & IV \\
\hline A2 B0 & 99,33 & $\mathrm{a}$ & 20,00 & $\mathrm{a}$ \\
A1 B0 & 97,33 & $\mathrm{a}$ & 19,36 & $\mathrm{a}$ \\
A0 B0 & 96,66 & $\mathrm{a}$ & 18,81 & $\mathrm{a}$ \\
A2 B1 & 85,33 & $\mathrm{~b}$ & 18,54 & $\mathrm{a}$ \\
A1 B1 & 65,33 & $\mathrm{c}$ & 15,48 & $\mathrm{~b}$ \\
A0 B1 & 57,33 & $\mathrm{~d}$ & 12,81 & $\mathrm{~b}$ \\
A2 B2 & 48,66 & $\mathrm{e}$ & 14,51 & $\mathrm{~b}$ \\
A2 B3 & 35,33 & $\mathrm{f}$ & 7,82 & $\mathrm{c}$ \\
A1 B2 & 29,33 & $\mathrm{~g}$ & 8,34 & $\mathrm{c}$ \\
A2 B4 & 27,33 & $\mathrm{~g}$ & 5,90 & $\mathrm{c}$ \\
A1 B3 & 24,66 & $\mathrm{~g}$ & 4,45 & $\mathrm{c}$ \\
A0 B2 & 18,00 & $\mathrm{~h}$ & 7,18 & $\mathrm{c}$ \\
A1 B4 & 15,33 & $\mathrm{~h}$ & 2,75 & $\mathrm{~d}$ \\
A0 B3 & 12,00 & $\mathrm{~h}$ & 2,56 & $\mathrm{~d}$ \\
A0 B4 & 7,33 & $\mathrm{i}$ & 1,44 & $\mathrm{~d}$ \\
\hline
\end{tabular}

Keterangan: Angka-angka yang diikuti dengan huruf yang sama tidak berbeda menurut Uji BNT 0,05. 
Hal ini sesuai dengan pernyataan Sumampow (2010), bahwa serbuk gergaji mempunyai sifat lambat lapuk sehingga sangat baikdalam menyimpan air dan mempertahankan kelembaban disekitar benih, ini terlihat pada kandungan kadar air selama proses penyimpanan benih pada media simpan serbuk gergaji dengan kadar air awal $44 \%$ mengalami penurunan pada penyimpanan 40 hari menjadi $40 \%$. Dengan kadar air benih yang terjaga maka benih tersebut mampu mempertahankan viabilitas benih untuk dapat digunakan saat diperlukan (Kartasapoetra, 2003).

Dalam proses penyimpanan, media simpan sekam padi mendorong terjadinya proses respirasi dari dalam benih cengkeh yang berkadar air tinggi. Kandungan kadar air benih yang disimpan dalam media simpan sekam padi mengalami penurunan kadar air sampai $25 \%$ pada penyimpanan 40 hari dari kadar air awal $44 \%$, yang mengakibatkan terjadinya penurunan viabilitas benih, laju perkecambahan dan indeks vigor. Proses respirasi dalam benih memerlukan oksigen dan melepaskan uap air, panas dan karbondioksida. Makin tinggi proses respirasi benih maka makin berkurang jumlah oksigen dalam benih akibatnya jumlah karbondioksida makin besar sehingga akan cenderung mempercepat aktivitas metabolisme dalam benih yang mengakibatkan terjadinya kemunduran bahkan kematian benih tersebut, sehingga benih tidak dapat disimpan dalam jangka waktu yang lama (Sutopo, 1993).

Hasil penelitian menunjukan persentase perkecambahan yang rendah adalah pada benih cengkeh yang disimpan tanpa menggunakan media simpan dengan nilai rata-rata perkecambahan 38,26 \%. Kamil (1982), menyatakan bahwa proses penyimpanan benih tanpa menggunakan media simpan menunjukan bahwa persentase perkecambahan benih sangat rendah. Benih memerlukan waktu yang lebih lama untuk tumbuh bahkan mengakibatkan embrio menjadi mati. Kemunduran benih dapat diartikan sebagai turunnya kualitas benih, sifat maupun viabilitas benih yang mengakibatkan rendahnya vigor benih dan buruknya pertanaman serta rendahnya produksi. Kemunduran benih menyebabkan kemunduran mutu fisiologis yang mengakibatkan perubahan menyeluruh di dalambenih baik fisik, fisiologi maupun kimiawi.

Gejala benih yang telah mundur adalah menurunnya daya berkecambah dan kehilangan kemampuan untuk tumbuh pada kondisi suboptimum. Gejala kemunduran benih dapat diamati dari segi biokimia benih seperti aktivitas enzim, tingkat respirasi, dan kebocoran metabolitnya. Kemunduran benih menghasilkan persentase perkecambahan benih yang rendah, terjadi penundaan perkecambahan, pertumbuhan kecambah yang lambat, kehilangan potensi tumbuh di lapang, menurunnya resistensi terhadap kondisi stres lingkungan, kehilangan hasil dan meningkatnya jumlah kecambah abnormal. Kadar air sangat menentukan viabilitas benih, sehingga untuk mempertahankan daya simpannya kadar air benih diusahakan tetap tinggi atau diatas batas kadar air kritiknya. Kadar air benih selama penyimpanan dipengaruhi olehkadar air awal, kondisi ruang simpan dan wadah simpan.

\section{Pengaruh Periode Simpan Terhadap Viabilitas Benih Cengkeh}

Hasil pengamatan setelah periode penyimpanan benih menunjukan terjadinya penurunan viabilitas benih. Tingkat penurunan viabilitas semakin tinggi sejalan dengan semakin lamanya waktu penyimpanan benih. Hal ini terlihat pada perlakuan lama penyimpanan benih cengkeh selama 40 hari (B4) yang menunjukan penurunan viabilitas benih, laju perkecambahan dan indeks vigor. Meskipun demikian tingkat penurunan viabilitas masih dapat ditekan dengan memberikan perlakuan pada proses penyimpanan benih.

Pada perlakuan lama penyimpanan benih menunjukan bahwa benih cengkeh yang langsung ditanam tanpa perlakuan penyimpanan (B0) mempunyai nilai persentase perkecambahan rata-rata $97,77 \%$. Sedangkan pada benih yang diberi perlakuan penyimpanan, yang memiliki persentase perkecambahan yang lebih tinggi yakni benih yang disimpan selama 10 hari (B1) dengan nilai persentase perkecambahan rata-rata $70,88 \%$, diikuti dengan penyimpanan benih selama 20 hari (B2) dengan nilai rata-rata perkecambahan 32.00 dan penyimpanan 30 hari (B3) 24,00\%. Penyimpanan benihselama 40 hari (B4) memiliki persentase perkecambahan yang rendah yakni $15,11 \%$.

Sadjad (1972) menjelaskan bahwa proses kemunduran benih adalah perubahan yang tidak dapat balik, yang mengurangi kapasitas hidup benih dan membawa benih pada taraf kehilangan daya kecambah dan kekuatan tumbuh yang baik. Proses kemunduran benih tidak dapat dicegah atau dihindarkan melainkan yang dapat dilakukan hanyalah mengurangi kecepatannya dengan melakukan perlakuan pada penanganan penyimpanan benih yang baik dan benar.

Proses perkecambahan itu sendiri merupakan serangkaian kompleks dari perubahan-perubahan morfolgi, fisiologi dan biokimia. Protein, pati, dan lipid setelah dirombak oleh enzim-enzim digunakan sebagai bahan penyusun pertumbuhan di daerah-daerah yang merupakan titik-titik tumbuh dan sebagai bahan bakar respirasi Untuk proses perkecambahan benih memerlukan air, oksigen, suhu dan cahaya yang cukup. Terbatasnya salah satu dari keempat faktor tersebut dapat menghalangi proses perkecambahan benih, sehingga pencegahan berkecambah selama penyimpanan dapat dilakukan dengan cara mengatur faktor tersebut didalam tempat penyimpanan (Sutopo, 2002).

\section{Pengaruh Interaksi Antara Media dan Periode Simpan Terhadap Viabilitas Benih Cengkeh ( $S$. aromaticum L.)}

Interaksi antara media dan periode simpan terhadap viabilitas benih cengkeh berdasarkan hasil analisis keragaman pada daya kecambah dan analisi 
keragaman indeks vigor benih cengkeh menunjukan pengaruh yang nyata terhadap viabilitas benih cengkeh.

Hasil pengamatan daya kecambah benih cengkeh menunjukanbahwa benih yang memiliki persentase perkecambahan lebih baik adalah pada benih cengkeh tanpa perlakuan penyimpanan yakni A2B0, A1B0 dan A0B0 dengan nilai rata-rata daya kecambah yakni 99,33, 97,33 dan 96,66\%.

Standar mutu benih cengkeh dalam bentuk biji salah satunya adalah mempunyai daya kecambah minimal $85 \%$ (Permentan No. 50, 2015). Biji cengkeh bersifat rekalsitran dan mempunyai daya berkecambah yang tinggi yakni 95-100\%, untuk itu biji cengkeh harus segera dikecambahkan setelah diambil dari lapangan/pohon induk (Ditjenbun, 1985).

Persentase perkecambahan benih dengan interaksi antara perlakuan media simpan dan periode simpan menunjukan bahwa benih yang disimpan pada media simpan serbuk gergaji dengan lama penyimpanan 10 hari (A2B1) memperlihatkan persentase perkecambahan yang lebih baik yakni $85,33 \%$ bila dibandingkan dengan persentase perkecambahan benih yang disimpan pada media simpan sekam padi dengan lama penyimpanan 10 hari (A1B1) yakni 65,33\%. Persentase perkecambahan benih cengkeh terus menurun sejalan dengan lamanya waktu penyimpanan benih. Setelah benih disimpan selama 20 hari pada media simpan sekam padi (A1B2) mempunyai persentase perkecambahan 29,33\%, penyimpanan 30 hari pada media simpan sekam padi (A1B3) mempunyai persentase perkecambahan $24,66 \%$ dan daya kecambah semakin menurun terlihat pada penyimpanan 40 hari dengan media simpan sekam padi (A1B4) yakni $15,33 \%$. Sedangkan pada benih yang disimpan selama 20 hari pada media simpan serbuk gergaji (A2B2) mempunyai persentase perkecambahan $48,66 \%$, penyimpanan 30 hari pada media simpan serbuk gergaji (A2B3) mempunyai persentase perkecambahan $35,33 \%$ dan daya kecambah semakin menurun terlihat pada penyimpanan 40 hari pada media simpan serbuk gergaji (A2B4) yakni 27,33\%.

Sesuai pernyataan yang disampaikan oleh Mabesa (1983) dalam Kuswanto (1997), bahwa semakin lama benih disimpan maka akan terjadi kemunduran benih. Lebih lanjut dikatakan bahwa proses kemunduran benih (deteriosasi) merupakan proses yang tidak dapat ditawar, pasti terjadi pada semua benih, yang berbeda hanyalah laju deteriorasinya saja. Hal ini juga terjadi pada benih cengkeh semakin lama di simpan maka terjadi kemunduran benih apalagi pada perlakuan penyimpanan tanpa media simpan dengan persentase perkecambahan terendah. Pada perlakuan penyimpanan tanpa media simpan dengan lama penyimpanan benih 10 hari (A0B1) menunjukan bahwa persentase perkecambahan yakni $57,33 \%$ dan persentase perkecambahan terendah yakni 7,33\% pada lama penyimpanan 40 hari.

Kuswanto (1997) menyatakan bahwa proses kemunduran benih dipengaruhi oleh dua hal, yaitu: 1) sifat genetis benih, kemunduran benih yang disebabkan oleh sifat genetis yang biasa disebut peristiwa deteriorasi kronologis. Artinya, walaupun benih ditangani dengan baik dan faktor lingkungan mendukung, namun proses deteriorasi akan tetap berlangsung; dan 2) lingkungan: proses ini biasa disebut deteriorasi fisiologis, yang disebabkan oleh adanya faktor lingkungan yang tidak sesuai dengan persyaratan penyimpanan benih.

Untuk mendapatkan benih yang baik sebelum disimpan maka benih harus benar-benar masak dipohon atau biji sudah mencapai kematangan fisiologis. Pemilihan benih dan cara pemyimpanan yang tepat merupakan cara untuk mengurangi laju kemunduran benih, sehingga viabilitas benih tetap dapat dipertahankan selama periode penyimpanan (Sutopo, 1993).

Vigor benih dicerminkan oleh dua vigorkekuatan tumbuh dan daya simpan benih. Kedua nilai fisiologi ini menempatkan benih pada kemungkinan kemampuannya untuk tumbuh menjadi tanaman normal meskipun keadaan biofisik di lapangan produksi suboptimum. Vigor benih yang tinggi dicirikan antara lain tahan disimpan lama, cepat dan merata tumbuhnya serta mampu menghasilkan tanaman dewasa yang normal dan berproduksi baik, dalam keadaan lingkungan tumbuh yang sub optimal. Benih yang mempunyai daya simpan yang lama mencirikan vigor benih yang tinggi setelah mengalami penyimpanan dalam waktu yang lama benih masih mampu tumbuh normal (Sudjadi, 2006).

Novita (2017), dalam hasil penelitian mengemukakan bahwa biji cengkeh yang diambil dari buah yang telah masak fisiologis (berwarna ungu kehitaman) menghasilkan jumlah kecambah normal yang lebih tinggi dan mempunyai persentase perkecambahan yang lebih baik.

\section{KESIMPULAN}

Berdasarkan hasil penelitian maka kesimpulan yang dapat diambil sebagai berikut:

1. Perlakuan media simpan, lama penyimpanan dan interaksi perlakuan media simpan dan lama penyimpanan memberikan pengaruh yang nyata pada perkecambahan benih cengkeh.

2. Secara umum, media simpan serbuk gergaji merupakan media yang baik bagi penyimpanan benih cengkeh. Hal ini terlihat pada hasil rata-rata daya berkecambah benih cengkeh yang disimpan pada media simpan serbuk gergaji yakni 59\% sedangkan pada media simpan sekam padi yakni $46 \%$. Perlakuan lama penyimpanan dalam meningkatkan viabilitas benih cengkeh yang lebih baik ditunjukan pada benih yang disimpan pada serbuk gergaji dengan lama penyimpanan selama 10 hari memberikan hasil yang lebih baik yakni $85 \%$ jika dibandingkan dengan sekam padi pada lama penyimpanan 10 hari dengan persentase perkecambahan $65 \%$.

\section{DAFTARPUSTAKA}

Anonim, 2009. Pedoman Praktis Budidaya Cengkeh. http://balittri.litbang.deptan.go.id/database/unggu lan/bookletcengkeh.pdf (15 Maret 2017). 
Direktorat Jenderal Perkebunan. 2016. Statistik Perkebunan Indonesia. Cengkeh 2014-2015. Kementerian Pertanian. Jakarta.

Direktorat Jenderal Perkebunan. 1985. Pedoman pembibitan tanaman cengkeh. Deptan, Jakarta. 43 hal.

Kamil. 1982. Teknologi Benih. Jilid 1. PT. Angkasa Raya. Padang.

Kartasapoetra, A.G. 2003. Teknologi Benih, Pengolahan Benih dan Tuntunan Praktikum. Bina Akasara, Jakarta.

Kuswanto. 1997. Dasar-dasar Teknologi, Produksi dan Sertifikasi Benih. Yogyakarta.

Novita. H. 2017. Penentuan Hitungan I dan II Serta Kriteria Kecambah Normal Pada Uji Daya Berkecambah Benih Cengkeh. BBPPTP Ambon.

Permentan No. 50. 2015. Peraturan Menteri Pertanian No. 50/Permentan/KB.020/9/2015 tentang Produksi, Sertifikasi, Peredaran dan Pengawasan Benih Tanaman Perkebunan. Kementan. Jakarta.
Sadjad, S. 1972. Kertas Merang untuk Uji Viabilitas Benih di Indonesia. Fakultas Pertanian Institut Pertanian Bogor.

Sadjad, S. 1980. Panduan Pembinaan Mutu Benih di Indonesia. Lembaga Afiliasi Institut Pertanian Bogor.

Schmidt, L. 2000. Pedoman Penanganan Benih Tanaman Hutan Tropis dan Subtropis. Jakarta.

Sudjadi, 2006. Biologi dan Sains. Yudistira. Jakarta.

Sumampow, D.M.F. 2010. Jurnal.Viabilitas Benih Kakao (Theobroma cacao L.) Pada Media Simpan Serbuk Gergaji. Fakultas Pertanian Universitas Sam Ratulangi Manado.

Sutopo, L. 1993. Teknologi Benih. Fakultas Pertanian Universitas Brawijaya. Rajawali Pers.

Sutopo, L. 2002. Teknologi Benih. Edisi Revisi. Fakultas Pertanian Universitas Brawijaya. Penerbit PT. Raja Grafindo Persada. Jakarta.

Yitnosumarto, S. 1993. Percobaan Perancangan, Analisis dan Interprestasinya. Jakarta: Gramedia Pustaka Utama. 